\title{
FENOMENA KESEHATAN PERKEMBANGAN SEKSUAL DAN PERAN ORANG TUA MILD RETARDATION DALAM PENDIDIKAN SEKS
}

\author{
Arbania Fitriani \\ Email: arbania@esaunggul.ac.id
}

\author{
Fakultas Psikologi Universitas Esa Unggul
}

\begin{abstract}
This Study aims to investigates what is the role of parents with mild retardation child in efforts to provide sex education. Researcher also want to see the health of sexual development as well as the problems that arise in connection with these aspects. The method used in this research is qualitative method. The technique used in collecting data is interview and observation techniques. Data collection tools in this study were interview guidelines, observation sheets, and tape recorders. The number of subjects is 4 people, 3 of them are mothers and 1 subject is significant others / aunts. From the results of the study, it was found that all subjects had implemented sex education within the guidances of the American Association of Pediatrics without them knowing it. The average subject applies democratic parenting and sometimes is over protected. All subject children experienced healthy and normal sexual development. In the sexual aspect, the support needed for children who are female is greater than men. The party most involved in providing sex education is the mother. The factor that makes the subject willing to apply sex education is fear if the child experiences something unpleasant in the aspect of his sexuality.
\end{abstract}

Keywords: Mentally Retarded, Mild Retardation, Sex Education, Parenting, Parents

Abstrak. Penelitian ini bertujuan untuk menyelidiki apa peran orang tua dengan anak retardasi ringan dalam upaya memberikan pendidikan seks. Peneliti juga ingin melihat kesehatan perkembangan seksual serta masalah yang muncul sehubungan dengan aspek-aspek ini. Metode yang digunakan dalam penelitian ini adalah metode kualitatif. Teknik yang digunakan dalam mengumpulkan data adalah teknik wawancara dan observasi. Alat pengumpulan data dalam penelitian ini adalah pedoman wawancara, lembar observasi, dan tape recorder. Jumlah subjek adalah 4 orang, 3 di antaranya adalah ibu dan 1 subjek signifikan lainnya / tante. Dari hasil penelitian, ditemukan bahwa semua subjek telah menerapkan pendidikan seks dalam bimbingan American Association of Pediatrics tanpa mereka sadari. Subjek rata-rata menerapkan pola asuh yang demokratis dan terkadang terlalu dilindungi. Semua anak-anak subjek mengalami perkembangan seksual yang sehat dan normal. Dalam aspek seksual, dukungan yang dibutuhkan untuk anak-anak yang perempuan lebih besar daripada laki-laki. Pihak yang paling terlibat dalam memberikan pendidikan seks adalah ibu. Faktor yang membuat subjek mau menerapkan pendidikan seks adalah ketakutan jika anak mengalami sesuatu yang tidak menyenangkan dalam aspek seksualitasnya.

Kata Kunci: Keterbelakangan mental, Keterbelakangan Ringan, Pendidikan Seks, Pengasuhan Anak, Orang Tua.

28 | Psychophedia Jurnal Psikologi Universitas Buana Perjuangan 


\section{Pengantar}

Pada dasarnya, penyandang tunagrahita mampu didik mempunyai karakteristik yang tidak jauh berbeda dari individu normal. Dewasa ini, banyak ahli menggunakan istilah tunagrahita mampu didik untuk individu yang tidak mendapat stimulasi dari lingkungan disebabkan oleh pola asuh yang tidak adekuat atau karena faktor genetis (Hallahan \& Kauffman, 1994). Pendidikan dapat dikatakan sebagai salah satu bentuk stimulus yang menjadi satu hal penting dan berarti bagi penyandang tunagrahita mampu didik Penyelenggaraan pendidikan bagi individu dengan cacat mental/tunagrahita di Indonesia mempunyai landasan hukum yang kuat sejak tahun 1945 (Mangunsong dkk., 1998).

Salah satu bentuk pendidikan yang dibutuhkan oleh penyandang tunagrahita mampu didik adalah pendidikan seks. Menurut Grossman (dalam Payne \& Patton, 1981) penyandang tunagrahita mampu didik juga memiliki dorongan seks, dapat jatuh cinta, dan keinginan untuk menikah. Apa yang telah disebutkan Grossman sejalan dengan apa yang tertulis dalam American Academy Of Pediatrics dalam Sexually Education of Children and Adolescents with Developmental Disabilities (RE9603) yakni, "persons with disabilities have similar curiosities, drives and interests in their own bodies and in the bodies of others". Hal ini memperjelas bahwa penyandang tunagrahita terutama yang mampu didik ternyata juga mempunyai kebutuhan seksual sebagaimana individu normal. Adanya kebutuhan seksual ini secara otomatis melahirkan kebutuhan informasi yang cukup mengenai pemenuhan kebutuhan tersebut sesuai dengan nilai yang dapat diterima oleh masyarakat sekitarnya. Van Dyke et al (1995) dalam Journal Down Syndrome Research and Practice vol. 3 , issue 2 menyatakan bahwa sebagai manusia, individu dengan disability mempunyai hak yang sama dengan individu normal dalam mengekspresikan kebutuhan seksualnya sehingga mendapatkan kepuasan. Hal sserupa juga diungkapkan oleh Fegan \& Rauch (1993) bahwa hak untuk mengekspresikan kebutuhan seksual pada individu dengan disability merupakan hak yang besifat mendasar. Seperti halnya individu yang normal, penyandang tunagrahita juga perlu mendapatkan pendidikan seks untuk menghindari terjadinya eksperimen tersembunyi yang dapat mengakibatkan kesulitan pada masa mendatang.

Banyak penelitian yang telah dilakukan berkaitan dengan adanya eksploitasi seksual dan juga sexual abuse yang dialami penyandang tunagrahita. Schwab (dalam Van Dyke et al 1995) menyebutkan bahwa:

Numerous expect in physical and sexual abuse acknowledge that mentally disabled individual is particularly vulnarable to sexual exploitation and abuse.

The Disabled Women's Network of Canada (Ridington dalam Nosek \& Howland, 1998) meneliti 245 wanita dengan disability dan menemukan $40 \%$ diantaranya mengalami eksploitasi, dan $12 \%$ diantaranya 'dicabuli'. Penelitian lain yang dilakukan oleh Sobsey 
\& Doe (dalam Nosek \& Howland, 1998) menemukan bahwa dari 166 kasus eksploitasi, $70 \%$ diantaranya adalah individu yang mengalami hendaya dalam aspek kognitifnya. Pada survey yang dilakukan terhadap 62 wanita oleh The Ontario Ministry of Community and Social Services (dalam Nosek \& Howland, 1998) ditemukan bahwa perbandingan antara wanita dengan disability dan wanita normal yang mengalami kekerasan adalah $33 \%$ banding $22 \%$. Sedangkan yang mengalami sexually abuse perbandingannya adalah 40 $\%$ banding $37 \%$. Selain itu juga dilaporkan dari sejarah perlakuan sexual abuse yang tercatat, ditemukan bahwa $25 \%$ remaja wanita penyandang tunagrahita mengalami perlakuan seks yang tidak sehat.

Selain kemungkinan mengalami eksploitasi seksual, penyandang tunagrahita dengan keterbatasan kognitif yang berimplikasi pada pemahaman terhadap aspek seksual yang dimilikinya juga sangat beresiko untuk tertular penyakit menular seksual. Dalam studi yang dilakukan Stone (dalam Van Dyke et al 1995) ditemukan bahwa individu dengan disability memiliki resiko peningkatan untuk tertular penyakit menular seksual (PMS) 50-90 \% diantaranya adalah resiko tertular gonorrhea. Jacobs et al (1989) menyatakan bahwa adanya karakteristik khusus seperti hendaya dalam aspek intelektualitas pada penyandang tunagrahita menyebabkan resiko terinfeksi virus HIV menjadi setinggi populasi normal.

Patut diakui bahwa pemberian pendidikan seks pada penyandang tunagrahita khususnya yang mampu didik
Juni 2020 - November 2020

masih menjadi sebuah kontroversi. Pembicaraan mengenai pendidikan seks ini sering ditolak oleh orangtua dari penyandang tunagrahita. Penolakan ditimbulkan oleh beberapa hal sebagaimana disebutkan dalam Jurnal Pediatrics vol. 97, no. 2 (1996). Penolakanyang pertama karena fokus orangtua pada ketidakmampuan anak ketimbang anak itu sendiri. Selanjutnya disebabkan oleh adanya ketakutan apabila pembicaraan mengenai seksualitas ini akan mendorong timbulnya perilaku seksual yang tidak diinginkan dan ketakutan akan kehamilan atau eksploitasi. Alasan lain adalah kesulitan dalam memutuskan tentang apa yang akan disampaikan dan bagaimana caranya. Alasan terakhir adalah adanya ketidakyakinan orangtua mengenai sejauh mana anak akan mengerti apa yang telah disampaikan.

Beranjak dari fenomena-fenomena tersebut di atas beserta kurangnya penelitian mengenai pentingnya pendidikan seks bagi penyandang tunagrahita khususnya yang mampu didik di Indonesia, maka timbullah permasalahan yang hendak diteliti. Permasalahan yang ingin diteliti adalah bagaimana peran orangtua anak tunagrahita mampu didik dalam upaya pemberian pendidikan seks. Permasalahan lain yang hendak diteliti adalah bagaimana gambaran aspek perkembangan seksual dari penyandang tunagrahita mampu didik dan bentuk dukungan yang dibutuhkan dalam rangka mencapai perkembangan seksual yang sehat secara fisik maupun psikologis.

Yang menjadi subyek dalam penelitian ini adalah orangtua dari anak tunagrahita mampu didik. Namun yang akan 
diwawancarai oleh peneliti hanyalah salah satu dari pihak orangtua atau significant others. Yang ditekankan di sini adalah pihak ibu dari anak tunagrahita mampu didik karena berdasarkan penelitian Thornburg (dalam Aini, 2001) ditemukan bahwa $17 \%$ pendidikan seks berasal dari ibu dan kurang lebih $2 \%$ berasal dari ayah. Selain itu, menurut Hassiotis dan Heller et al. (dalam Porter \& McKenzie, 2000) ibu adalah pihak yang lebih aktif dalam pengasuhan dan perawatan anak. Ibu juga merupakan pihak yang lebih memperhatikan tekanan emosi dalam keluarga sehubungan dengan hambatan anak dan juga tuntutan pengasuhan dan dukungan lain yang dibutuhkan anak dengan disability (Koegel et al. dalam Porter \& McKenzie, 2000). Dan yang terpenting pihak ibulah yang seringkali lebih terlibat dalam pemberian terapi atau pemberian pendidikan pada anak dengan disability (Padeliadu dalam Porter \& McKenzie, 2000).Yang turut menjadi pertimbangan lain yakni mengingat dalam tahap perkembangan anak secara umum, sebagaimana terlihat dalam kehidupan sehari-hari maupun dalam literatur seperti dalam Papalia, Olds, \& Feldman (2001), pihak ibulah yang lebih mengikuti tahapan perkembangan anak dibandingkan pihak ayah. Oleh karenanya, peneliti berasumsi bahwa pihak ibu akan lebih mampu menjawab pertanyaan-pertanyaan peneliti, utamanya untuk hal yang sampai saat ini masih sangat sensitif yakni aspek seksualitas anak. Adapun metode yang dipakai oleh peneliti adalah metode kualitatif dengan menggunakan metode wawancara dan observasi. Pemilihan metode ini atas dasar
Juni 2020 - November 2020

pertimbangan sensitivitas permasalahan yakni aspek seksualitas anak yang masih tergolong tabu di Indonesia (Pohan). Selain itu, dengan menggunakan metode kualitatif diharapkan informasi yang cukup mendalam dapat tergali lebih luas lagi.

\section{Landasan Teori}

Pendidikan seks pada masa pembentukan anak sangat penting dilakukan. Pendidikan ini perlu untuk menghindari terjadinya eksperimen tersembunyi yang dapat mengakibatkan rasa bersalah, malu, takut, atau kesulitan lainnya pada masa dewasa nanti (Marisa dalam Warta Sosial, 2001). Sikap orangtua yang malu memberikan pendidikan seks akan membuat anak takut untuk bertanya. Padahal bagi penyandang tunagrahita mampu didik, kekurangan informasi adalah kondisi yang berbahaya karena mungkin saja mereka melakukan eksperimen seksual sehingga menimbulkan dampak negatif bagi anak tersebut. Pendidikan seks ini kemudian menjadi terasa sangat penting untuk diberikan kepada penyandang tunagrahita mampu didik karena sebagaimana diungkapkan Thompson (1978), salah satu ciri mereka adalah sexually promiscuous atau melakukan hubungan seksual dengan siapa saja (freesex). Hal ini tentu saja tidak sehat bagi individu tersebut.

Pemberian pendidikan seks pada penyandang tunagrahita khususnya yang mampu dididik penting untuk mengembangkan level intelektualitas, menolong untuk meraih seksualitas yang sehat, mencegah kehamilan yang tidak 
diinginkan dan penyakit menular seksual, serta mengatasi masalah lain yang berkenaan dengan fungsi-fungsi seksual mereka (Schwab, 1992). Keterbatasan kognitif dan hendaya dalam fungsi adaptif dari penyandang tunagrahita membuat mereka seringkali mengalami permasalahan seksual yang cukup memprihatinkan. Van Dyke et al (1995) menyatakan bahwa hambatan kognitif dan bahasa yang mereka alami dapat menjadi predisposisi dari kehamilan yang tidak diinginkan, penyakit menular seks, dan eksploitasi seksual.

Bentuk lain yang mungkin dialami oleh penyandang tunagrahita sebagai akibat dari hendaya yang dimilikinya adalah child neglect. Salah satu bentuk child neglect menurut Ann (1998) adalah educational neglect yakni kesalahan pemberian pendidikan dalam kebutuhan khusus. Salah satu kebutuhan khusus itu adalah pendidikan seks.

Orangtua memiliki hak untuk menuntut pelayanan terbaik bagi anak mereka yang mengalami hambatan dalam setiap aspek kehidupan anak, khususnya aspek yang sulit seperti aspek seksual (Fegan \& Rauch, 1993). Seiring dengan hak tersebut, maka lahir pula kewajiban akan pemberian pendidikan kepada anak yang harus dipenuhi pihak orangtua, dimana orangtua adalah penanggung jawab terbesar dalam terpenuhinya pendidikan anak (Pohan). Pendidikan yang dimaksud di sini tidak hanya pendidikan formal namun termasuk juga pendidikan informal yang meliputi pendidikan seks. Menurut Brock \& Jenning (dalam Aini, 2001) orangtua adalah elemen yang seringkali
Juni 2020 - November 2020

hilang dalam pendidikan seks. Telah disebutkan sebelumnya bahwa anak terbelakang termasuk penyandang tunagrahita mampu didik juga memerlukan pendidikan seks. Konsekuensi dari kebutuhan tersebut adalah timbulnya tuntutan yang harus dipenuhi oleh orangtua dari penyandang tunagrahita mampu didik. Selama ini banyak kesalahpahaman yang berkembang mengenai penyandang tunagrahita berkaitan dengan upaya pemberian pendidikan kepada mereka. Salah satu kesalahpahaman terbesar menurut Thompson (1978) yakni "it is not appropriate and/or not worthwhile to attempt to educate and train the retarded resident”. Mangunsong dkk. (1998) mengatakan bahwa,

Konsekuensi dari pandangan negatif terhadap anak tunagrahita adalah bahwa mereka tidak hanya dihalanghalangi untuk melakukan apa yang mereka bisa lakukan, tetapi juga untuk mengembangkan keterampilan yang sebenarnya mereka mampu lakukan. ... Hanya karena intelegensinya, anak tunagrahita dibedakan, dieksploitasi dan dideprivasi

Anggapan bahwa tunagrahita tidak cocok diberikan pendidikan ataupun pelatihan ini kemudian berimplikasi secara negatif pada upaya pemberian informasi berupa pendidikan seks pada penyandang tunagrahita tersebut.

\section{Metode Penelitian}

\section{Subyek Penelitian}

Subyek yang akan menjadi sampel dalam penelitian ini adalah salah satu 
orangtua dari individu penyandang tunagrahita mampu didik atau significant others. Karakteristik dari penyandang tunagrahita yaitu yang tergolong mampu didik yang bisa diketahui melalui IQ anak yakni 55-69 (Wechsler) atau 55-68 (Stanford-Binet). Karakteristik lain yang perlu dimiliki oleh penyandang tunagrahita untuk dijadikan subyek dalam penelitian ini yakni remaja berusia minimal 15 tahun dengan pertimbangan bahwa usia yang paling terlambat bagi anak tunagrahita adalah mengalami masa puber adalah 14 tahun (Elkins et al. dalam Van Dyke et al, 1995). Sedangkan orangtua adalah salah satu orangtua subyek dan lebih diutamakan ibu karena berdasarkan penelitian pihak ibu merupakan pemberi kontribusi terbesar dalam pemberian pendidikan seks pada anak sehingga diharapkan informasi yang didapatkan bisa lebih kaya dan mendalam. Namun tidak tertutup kemungkinan untuk mewawancarai pihak ayah atau significant others yang lain jika ternyata di lapangan sulit untuk memenuhi standar tersebut. Orangtua atau significant others yang akan diwawancarai memiliki latar belakang pendidikan minimal SMU. Pembuatan batasan ini karena tingkat pendidikan subyek akan mempengaruhi kemampuan subyek untuk memahami dan menjawab pertanyaan peneliti.

\section{Teknik Pengambilan Data}

Pada umumnya pendekatan kualitatif mengunakan pendekatan purposif dimana sampel tidak diambil secara acak tetapi justru dipilih mengikuti kriteria (Poerwandari, 1998). Berdasarkan kenyataan tersebut, peneliti akan menggunakan teknik purposif dalam memilih subyek penelitian sebagai teknik utama yakni pengambilan sampel berdasarkan teori tertentu, atau berdasarkan konstruk operasional (theorybased operational construct sampling). Respoden ini dipilih berdasarkan kesediaan dan ketersediaan.

Menurut Sarantakos (dalam Poerwandari,1998), teknik pengambilan sampel dalam penelitian kualitatif umumnya menampilkan karakteristik (1) diarahkan tidak pada jumlah sampel yang besar, melainkan pada kasus-kasus tipikal sesuai kekhususan masalah penelitian; (2) tidak ditentukan secara kaku sejak awal, tetapi dapat berubah baik dalam hal jumlah maupun karakteristik sampelnya, sesuai dengan karakteristik konseptual yang berkembang dalam penelitian; dan (3) tidak diarahkan pada keterwakilan (dalam arti jumlah/peristiwa acak) melainkan pada kecocokan konteks.

Selanjutnya Patton (dalam Poerwandari 1998) mengatakan bahwa suatu penelitian kualitatif dapat melakukan penelitian secara mendalam pada kasus tunggal $(\mathrm{n}=1)$ yang dipilih secara purposif. Oleh karena itu, jumlah subyek dalam penelitian ini ditetapkan sebanyak 4 (empat) orang yakni pihak orang tua atau significant others lainnya yang dianggap memahami riwayat pertumbuhan dan perkembangan anak secara luas terutama segala hal yang berkaitan dengan aspek seksualitas anak. Alasan pemilihan jumlah sampel sebanyak 4 orang karena dengan jumlah tersebut diharapkan sudah bisa menggali semua informasi yang diperlukan untuk menjawab 
pertanyaan penelitian ini. Tidak tertutup kemungkinan bahwa jumlah dari sampel yang dipilih akan bertambah atau berkurang sesuai dengan ketersediaan subyek yang akan diteliti, demikian juga dengan pemahaman konseptual yang berkembang.

Dalam penelitian kualitatif, ada beberapa metode yang dapat digunakan untuk mengumpulkan data antara lain teknik wawancara, observasi, diskusi kelompok terfokus, analisis terhadap dokumen atau peninggalan (karya film, karya tulis, atau karya seni lain), atau analisis materi audio visual (Poerwandari, 1998). Dalam penelitian ini, penulis akan menggunakan metode wawancara mendalam pada orang tua anak tunagrahita mampu didik. Penulis juga akan menggunakan metode observasi terhadap subyek yang sedang diwawancarai sebagai data tambahan untuk memahami jawaban yang diberikan subjek terhadap pertanyaan peneliti.

Dalam penelitian ini, variasi yang akan digunakan adalah wawancara dengan pedoman terstandar. Penggunaan variasi ini ditujukan agar pembicaraan tidak meluas kepada hal yang tidak relevan dengan tujuan penelitian. Disamping itu, dengan teknik ini diharapkan bisa mempermudah pengklasifikasian informasi. Peneliti juga harus memperhatikan pedoman dalam perumusan wawancara. Menurut Smith et al. (dalam Poerwandari, 1998) pertanyaan haruslah netral, menghindari penggunaan istilah-istilah yang canggih, resmi, ataupun terlalu tinggi, terlebih dalam mewawancarai individu yang bukan mewakili kalangan ilmiah atau kalangan professional. Terakhir, peneliti juga sebaiknya menggunakan pertanyaan yang bersifat terbuka.

\section{Alat Pengumpul Data}

\subsection{Pedoman Interview}

Pedoman wawancara ini berguna agar wawancara tidak melebar dari tema yang telah ditetapkan sebelumnya. Pedoman wawancara ini dibuat berdasarkan masalah yang hendak diteliti dan disesuaikan dengan teori yang ada. Berikut adalah daftar kisikisi dari pertanyaan dalam pedoman wawancara.

Tabel 1 Kisi-Kisi Interview

\begin{tabular}{|c|c|}
\hline Kisi-Kisi & Contoh pertanyaan \\
\hline $\begin{array}{l}\text { Pertumbuhan } \\
\text { dan } \\
\text { Perkembanga } \\
\text { n Anak }\end{array}$ & $\begin{array}{l}\text { 1. Bagaimana kondisi ibu } \\
\text { dan lingkungan di } \\
\text { sekitar ibu pada saat } \\
\text { mengandung anak? } \\
\text { 2. Bagaimana kondisi } \\
\text { anak pada saat masih } \\
\text { dalam kandungan? } \\
\text { 3. Bagaimana riwayat } \\
\text { kelahiran dan } \\
\text { kesehatan anak dan } \\
\text { 4. Bagaimana riwayat } \\
\text { pertumbuhan anak } \\
\text { perkembangan dan } \\
\text { sebelum disekolahkan? } \\
\text { 5. Bagaimana riwayat } \\
\text { pertumbuhan anak } \\
\text { perkembangan an ana } \\
\text { secara keseluruhan? } \\
\text { 6. Bagaimana bentuk } \\
\text { pengasuhan yang } \\
\text { diberikan kepada anak } \\
\text { untuk merangsang } \\
\text { pertumbuhan dan } \\
\text { perkembangannya? } \\
\text { 7. Sejak kapan anda tahu } \\
\text { bahwa anak anda } \\
\text { berbeda dengan anak } \\
\text { yang normal? }\end{array}$ \\
\hline
\end{tabular}


Juni 2020 - November 2020

\begin{tabular}{|c|c|}
\hline & $\begin{array}{l}\text { 8. Bagaimana reaksi anda } \\
\text { pada saat pertama kali } \\
\text { mengetahuinya dan } \\
\text { bagaimana tindakan } \\
\text { tindakan selanjutnya? } \\
\text { 9. Bagaimana bentuk } \\
\text { dukungan yang } \\
\text { dibutuhkan anak } \\
\text { terhadap anda berkaitan } \\
\text { dengan hambatan yang } \\
\text { dialami anak? }\end{array}$ \\
\hline $\begin{array}{l}\text { Faktor-Faktor } \\
\text { yang Mempe- } \\
\text { ngaruhi } \\
\text { Pengasuhan }\end{array}$ & $\begin{array}{l}\text { 1. Apakah ada perbedaan } \\
\text { bentuk pengasuhan } \\
\text { sebelum dan sesudah } \\
\text { mengetahui bahwa } \\
\text { anak mengalami } \\
\text { hambatan? } \\
\text { 2. Apakah ada perbedaan } \\
\text { bentuk pengasuhan } \\
\text { pada masa kanak dan } \\
\text { pada masa remaja? } \\
\text { 3. Apakah kakak/adik, } \\
\text { teman-teman anak, } \\
\text { tetangga, teman kantor } \\
\text { (jika punya) memberi } \\
\text { dukungan kepada anda } \\
\text { dalam pengasuhan } \\
\text { kepada anak dalam } \\
\text { rangka membantu anak } \\
\text { untuk menyesuaikan } \\
\text { diri dengan } \\
\text { lingkungannya? } \\
\text { 4. Secara umum bentuk } \\
\text { pengasuhan apa yang } \\
\text { anda terapkan kepada } \\
\text { anak (khusus untuk } \\
\text { subjek)? }\end{array}$ \\
\hline $\begin{array}{l}\text { Permasalahan } \\
\text { Anak } \\
\text { Berkaitan } \\
\text { dengan Aspek } \\
\text { Seksualitas } \\
\text { Anak dan } \\
\text { Peran }\end{array}$ & $\begin{array}{lr}\text { 1.Usia berapa anak } \\
\text { mengalami menstruasi } \\
\text { dan bagaimana siklus } \\
\text { menstruasi anak? } \\
\text { 2.Bagaimana anak } \\
\text { menyesuaikan diri } \\
\text { dengan menstruasi yang }\end{array}$ \\
\hline
\end{tabular}

\begin{tabular}{|c|c|}
\hline orangtua & 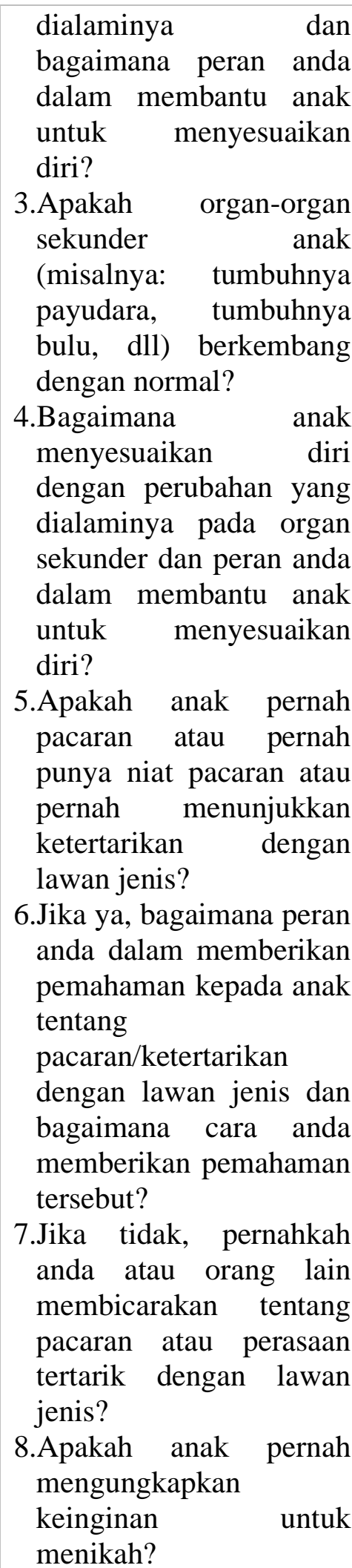 \\
\hline
\end{tabular}


9.Jika ya, bagaimana peran anda dalam memberikan pemahaman kepada anak tentang pernikahan dan konsekuensinya serta bagaimana cara anda memberikan pemahaman tersebut?

10.Jika tidak, pernahkah anda atau orang lain membicarakan tentang pernikahan kepada anak?

11.Menurut anda pelecehan seksual itu apa?

12.Apakah anak pernah mengalami pelecehan seksual?

13.Jika ya, dampak apa yang terjadi pada anak setelah mengalami pelecehan seksual tersebut?

14. Jika tidak, apa upaya anda untuk melidungi anak agar terhindar dari pelecehan seksual?

15. Apakah anda pernah meyampaikan kepada anak tentang hubungan suami istri (hub. Seksual) dan dampaknya jika dilakukan diluar nikah dan dengan sembarang orang?

16. Jika ya, bagaiamana cara anda menyampaikannya dan jika tidak apakah anda punya rencana untuk menyampaikannya?

17. Apakah anda pernah menyampaikan kepada
Juni 2020 - November 2020

anak bahwa anak anda

suatu saat bisa

mengandung dan

mempunyai bayi

kemudian mengajarkan kepada anak anda bagaimana cara mengasuh dan membesarkan bayi itu?

18. Jika ya, bagaimana cara anda menyampaikan dan jika tidak apakah anda punya rencana untuk menyampaikannya?

19. Apakah anda tahu tentang penyakit menular seksual dan bagaimana cara penularannya?

20. Apakah anda pernah menyampaikan tentang penyakit menular seksual kepada anak dan bagaimana penyakit menular seksual itu bisa menulari anak?

21.Jika ya, bagaimana cara anda menyampaikannya dan jika tidak apakah anda punya rencana untuk menyampaikannya?

22. Apakah anda pernah menyampaikan kepada anak tentang alat kontrasepsi beserta kegunannya, kenapa digunakan, dan kapan bisa/harus digunakan?

23.Jika ya, bagaimana cara anda menyampaikannya dan 


\begin{tabular}{|c|c|}
\hline & $\begin{array}{l}\text { jika tidak apakah anda } \\
\text { punya rencana untuk } \\
\text { menyampaikannya? } \\
\text { 24. Apakah anak pernah } \\
\text { memainkan alat } \\
\text { kelaminnya sendiri? } \\
\text { 25. Jika ya, apa tindakan } \\
\text { anda dan jika tidak, } \\
\text { apakah anda pernah } \\
\text { melakukan tindakan } \\
\text { antisipatif untuk } \\
\text { mencegah agar anak } \\
\text { tidak melakukan hal } \\
\text { tersebut? bentuk } \\
\text { 26. Secara umum, ben } \\
\text { dukungan apa yang } \\
\text { dibutuhkan anak } \\
\text { terhadap orang tuanya } \\
\text { dalam menyesuaikan } \\
\text { diri dengan } \\
\text { perkembangan } \\
\text { seksualitas anak? }\end{array}$ \\
\hline $\begin{array}{l}\text { Pendidikan } \\
\text { Seks }\end{array}$ & $\begin{array}{l}\text { 1. Pengertian pendidikan } \\
\text { seks menurut anda apa? } \\
\text { 2. Apakah anda } \\
\text { menerapkan pendidikan } \\
\text { seks kepada anak di } \\
\text { dalam rumah? } \\
\text { 3.Jika ya, faktor apa yang } \\
\text { membuat anda bersedia } \\
\text { untuk menerapkannya, } \\
\text { bagaimana bentuk } \\
\text { penerapannya, dan sejak } \\
\text { kapan diberikan? } \\
\text { 4. Jika tidak, apakah anda } \\
\text { akan menerapkannya, } \\
\text { faktor apa yang } \\
\text { membuat anda bersedia } \\
\text { untuk menerapkannya, } \\
\text { dan kapan anda akan } \\
\text { memulai untuk } \\
\text { memberikannya? } \\
\text { 5.Menurut anda, siapa }\end{array}$ \\
\hline
\end{tabular}

Juni 2020 - November 2020 yang paling berperan dalam upaya pemberian pendidikan seks kepada anak?

6.Apa harapan anda terhadap pemberian pendidikan seks kepada anak?

\subsection{Lembar Observasi}

Lembar ini akan digunakan untuk mencatat hal-hal penting yang terjadi selama situasi wawancara dan juga selama berlangsungnya penelitian. Yang akan dilakukan oleh peneliti sesuai dengan Banister et al (dalam Poerwandari, 1998) yakni : (a) deskripsi konteks (meliputi tanggal, waktu, dan tempat observasi); (b) deskripsi mengenai karakteristik orangorang yang diamati; (c) deskripsi tentang siapa yang melakukan observasi; (d)deskripsi mengenai perilaku orang yang diamati; (e) interpretasi sementara peneliti terhadap kejadian yang diamati; (f) pertimbangan mengenai alternatif interpretasi-interpretasi lain; (g) eksplorasi perasaan dan penghayatan peneliti terhadap kejadian yang diamati.

\subsection{Alat Perekam}

Alat perekam digunakan untuk merekam dialog yang terjadi selama proses wawancara sehingga bisa memudahkan peneliti dalam proses pengolahan. Alat perekam ini berbentuk tape recorder yang digunakan jika responden menyetujui penggunaan alat tersebut selama proses wawancara.

\section{Prosedur Penelitian}




\subsection{Persiapan Penelitian}

a. Pembuatan instrumen penelitian. Sebelum penelitian dilaksanakan, peneliti terlebih dahulu mempersiapkan instrumen penelitian berupa pedoman wawancara dan pedoman observasi. Pedoman wawancara dibuat berdasarkan masalah dalam penelitian ini dan disesuaikan dengan teori. Sedangkan pedoman observasi dibuat berdasarkan tuntunan dalam teori penelitian kualitatif. Setelah mendapatkan umpan balik dari pembimbing, peneliti kemudian menguji cobakan instrumen penelitian yang telah dibuat terhadap ibu dari individu penyandang tunagrahita mampu didik. Uji coba ini bertujuan untuk mengetahui seberapa jauh instrumen tersebut mampu menggali data yang dibutuhkan untuk menjawab permasalahan penelitian. Tujuan lain adalah untuk mengetahui seberapa jauh instrumen ini dapat dipahami oleh subyek. Setelah itu, peneliti kembali mengkonsultasikan instrumen penelitian pada pembimbing untuk kemudian dibuat perbaikan hingga siap untuk dipakai dalam penelitian lapangan.

b. Pemilihan subyek penelitian. Subyek yang dipilih dalam penelitian ini adalah subyek yang memiliki kriteria yang telah ditetapkan sebelumnya oleh peneliti.

\section{c. Menghubungi Dr. Soemiarti} Patmonodewo untuk meminta ijin melakukan penelitian di yayasan yang beliau kelola yakni SLB-C Swakarya.

d. Menghubungi kepala SLB-C Swakarya untuk meminta bantuan agar
Juni 2020 - November 2020

disediakan subyek yang sesuai dengan kriteria yang dibutuhkan oleh peneliti.

e. Menghubungi satu persatu subyek yang telah bersedia turut serta dalam penelitian ini untuk membuat janji wawancara.

f. Melakukan wawancara di rumah masing-masing subyek sesuai dengan perjanjian yang telah dibuat.

\subsection{Pelaksanaan Penelitian}

Wawancara dilakukan dalam beberapa waktu. Untuk subyek pertama, wawancara dilakukan sebanyak tiga kali yakni pada tanggal 17 Maret 2019, 24 Mei dan 9 Juni 2019. Untuk subyek ke dua, wawancara dilakukan sebanyak dua kali yakni pada tanggal 7 Maret 2019 dan tanggal 9 Juni 2019. Untuk Subyek ke tiga, wawancara dilakukan sebanyak dua kali yakni pada tanggal 17 Maret 2019 dan 14 Juni 2019. Sedangkan untuk subyek ke empat, wawancara dilakukan pada tanggal 3 April 2019 dan 14 Juni 2019. Proses wawancara dilakukan selama kurang lebih 45 menit. Wawancara dilakukan dengan menggunakan tape recorder. Sewaktu satu sisi kaset habis peneliti mendengar kembali hasil rekaman untuk memastikan bahwa dialog terekam dengan baik. Pada saat wawancara, anak yang menjadi fokus penelitian tersebut berada tidak jauh dari tempat belangsungnya wawancara sehingga terkadang peneliti atau subyek yang diwawancarai menanyakan sesuatu kepada anak tersebut untuk menegaskan jawaban yang diberikan. Setelah selesai proses wawancara, peneliti kemudian mengetik 
hasil wawancara secara verbatim untuk dianalisa lebih lanjut.

\subsection{Teknik Analisa Data}

Dalam menganalisa data yang telah diperoleh, peneliti berusaha mengikuti langkah-langkah dalam analisa data yang dikemukakan oleh Patton (dalam Poerwandari, 2001:85) yakni,

1. Mengubah data mentah berupa rekaman suara ke dalam bentuk tertulis secara verbatim, yaitu melalui proses transkripsi rekaman diskusi dan wawancara.

2. Membaca data secara berulang - ulang untuk mengetahui topik - topik yang muncul dan memperoleh gambaran tentang data keseluruhan.

3. Melakukan koding dan mengelompokkan data masing - masing subyek ke dalam kategori - kategori yang sesuai dengan masalah penelitian.

4. Menyusun rangkuman data secara kronologis. Melakukan analisa terhadap data yang telah dikoding dan dikategorisasi. Analisa dilakukan secara individual terhadap setiap subyek pada wawancara untuk mengetahui dinamika dan pengalaman mereka.

5. Melakukan perbandingan terhadap gambaran dan hasil analisa dan semua subyek dalam wawancara untuk mendapatkan hasil analisa umum.

6. Mencoba menjelaskan data hasil analisa berdasarkan teori yang telah disusun.

\section{Hasil Dan Pembahasan Penelitian}

Juni 2020 - November 2020

Gambaran Demografi Subyek

Tabel berikut diberikan gambaran umum mengenai data pribadi subyek yang diwawancarai.

\section{Tabel 2 Gambaran Subyek}

\begin{tabular}{|c|c|c|c|c|}
\hline & $\begin{array}{l}\text { Subyek } \\
\text { I }\end{array}$ & $\begin{array}{l}\text { Subyek } \\
\text { II }\end{array}$ & $\begin{array}{l}\text { Subyek } \\
\text { III }\end{array}$ & $\begin{array}{l}\text { Subyek } \\
\text { IV }\end{array}$ \\
\hline $\begin{array}{l}\text { Usia } \\
\text { Subyek }\end{array}$ & 46 thn & 51 thn & 33thn & 38 thn \\
\hline $\begin{array}{l}\text { Usia } \\
\text { suami }\end{array}$ & 55 thn & 55 thn & 40 thn & 43 thn \\
\hline $\begin{array}{l}\text { Agama } \\
\text { subyek }\end{array}$ & Islam & Islam & Kristen & Islam \\
\hline $\begin{array}{l}\text { Agama } \\
\text { suami } \\
\text { subyek }\end{array}$ & Islam & Islam & Kristen & Islam \\
\hline $\begin{array}{l}\text { Suku } \\
\text { Bangsa } \\
\text { subyek }\end{array}$ & Jawa & Jawa & Jawa & Betawi \\
\hline $\begin{array}{l}\text { Suku } \\
\text { bangsa } \\
\text { suami } \\
\text { subyek }\end{array}$ & Jawa & $\begin{array}{l}\text { Kalima } \\
\text { ntan }\end{array}$ & Jawa & Bali \\
\hline $\begin{array}{l}\text { Pendidi } \\
\text { kan } \\
\text { subyek }\end{array}$ & $\begin{array}{l}\text { Tamat } \\
\text { SMU }\end{array}$ & $\begin{array}{l}\text { Tamat } \\
\text { Akade } \\
\text { mi }\end{array}$ & $\begin{array}{l}\text { Tamat } \\
\text { SMU }\end{array}$ & $\begin{array}{l}\text { Tamat } \\
\text { SMU }\end{array}$ \\
\hline $\begin{array}{l}\text { Pendidi } \\
\text { kan } \\
\text { suami } \\
\text { subyek }\end{array}$ & $\begin{array}{l}\text { Tamat } \\
\text { SMU }\end{array}$ & $\begin{array}{l}\text { Sarjana } \\
\text { Ekono } \\
\text { mi }\end{array}$ & $\begin{array}{l}\text { Tamat } \\
\text { SD }\end{array}$ & $\begin{array}{l}\text { Tamat } \\
\text { SMU }\end{array}$ \\
\hline $\begin{array}{l}\text { Pekerja } \\
\text { an } \\
\text { subyek }\end{array}$ & $\begin{array}{l}\text { Ibu } \\
\text { Rumah } \\
\text { Tangga }\end{array}$ & $\begin{array}{l}\text { Ibu } \\
\text { Rumah } \\
\text { Tangga }\end{array}$ & $\begin{array}{l}\text { Ibu } \\
\text { Rumah } \\
\text { Tangga }\end{array}$ & $\begin{array}{l}\text { Ibu } \\
\text { Ruma } \\
\text { h } \\
\text { Tangg } \\
\text { a }\end{array}$ \\
\hline $\begin{array}{l}\text { Pekerja } \\
\text { an } \\
\text { suami } \\
\text { subyek }\end{array}$ & $\begin{array}{l}\text { Wirasw } \\
\text { asta }\end{array}$ & $\begin{array}{l}\text { Dewan } \\
\text { Audit } \\
\text { Bank } \\
\text { Mandiri }\end{array}$ & Satpam & $\begin{array}{l}\text { Wiras } \\
\text { wasta }\end{array}$ \\
\hline $\begin{array}{l}\text { Usia } \\
\text { penyan } \\
\text { dang } \\
\text { tunagra } \\
\text { hita }\end{array}$ & $\begin{array}{l}22 \\
\text { tahun }\end{array}$ & $\begin{array}{l}20 \\
\text { tahun }\end{array}$ & 18 tahun & $\begin{array}{l}19 \\
\text { tahun }\end{array}$ \\
\hline
\end{tabular}




\begin{tabular}{|l|l|l|l|l|}
\hline Hubung & Ibu dari & Ibu dari & Kakak & Ibu \\
an & penyan & penyan & kandung & dari \\
subyek & dang & dang & dari & penya \\
dgn & tunagra & tunagra & penyand & ndang \\
penyan & hita & hita & ang & tunagr \\
dang & & & tunagrah & ahita \\
tunagra & & & ita & \\
hita & & & & \\
\hline
\end{tabular}

\section{Analisis Antar Subyek}

\subsection{Bentuk Pengasuhan}

Bentuk pengasuhan yang diberikan oleh keempat subyek hampir serupa. Mereka rata-rata memberikan perhatian, mengistimewakan, ataupun memberi kasih sayang secara penuh kepada subyek berkaitan dengan ketunagrahitaannya. Mereka cenderung lebih mengontrol dan mengarahkan hampir semua kegiatan anak. Secara umum mereka berusaha untuk mengasuh anak secara demokratis yakni penggabungan hal positif dari bentuk pengasuhan permisif dan otoriter (Baumrind, 1997 dalam Aini, 2001). Namun diantara para subyek yakni subyek II dan IV, mereka terkadang cenderung otoriter dalam hal tertentu seperti pada kasus surat yang tidak diposkan oleh subyek II atau pembatasan ruang gerak seperti yang dilakukan subyek IV.

Pemberian bentuk pengasuhan antara masa kanak-kanak dan masa remaja dari subyek I dan III, tidak terdapat perbedaan. Hal ini disebabkan karena anak (khususnya yang menyadang tunagrahita) dari para subyek tersebut tidaklah terlalu menuntut yang macam-macam. Sedangkan untuk subyek II dan IV, pemberian pengasuhan kepada anak antara masa kanak-kanak dan remaja terdapat perbedaan. Perbedaan ini
Juni 2020 - November 2020 lebih kepada bentuk penjagaan. Untuk subyek II, perbedaan yang timbul yakni ketika anak subyek sudah remaja penjagaan dan dukungan subyek sudah tidak sebesar ketika anak masih kanak-kanak yang belum bisa melakukan segalanya sendirian. Namun subyek masih harus mendampingi terusmenerus. Kebalikan dari subyek II, perbedaan pada subyek IV yakni ketika anak dari subyek sudah remaja, subyek justru lebih ketat dalam menjaga anaknya dan kekhawatirannya juga lebih besar. Adanya perbedaan pola asuh ini terkait dengan karakteristik khusus remaja penyandang tunagrahita termasuk yang mampu didik yakni timbulnya keinginan untuk bersosialisasi secara luas (Porter \& McKenzie, 2000). Perubahan karakter pada individu penyandang tunagrahita mampu didik pada saat remaja inilah yang menimbulkan respon yang berbeda dari masing-masing subyek.

\subsection{Karakteristik Orangtua}

Dalam menghadapi kenyataan akan ketunagrahitaan anaknya, keempat subyek bereaksi sama yakni sempat kaget dan sedih. Hal ini sesuai dengan apa yang diungkapkan oleh Porter \& McKenzie (2000) bahwa reaksi yang seringkali timbul pada orang tua dari individu penyandang tunagrahita adalah kesedihan, rasa kehilangan, dan dukacita yang kronis. Untuk subyek II dan IV, mereka sempat stres namun tidak berlangsung lama. Untuk subyek I, coping stres diperoleh dari pendekatan agama. Pada subyek II dan IV, kesemuanya berhasil mengatasi kesedihan setelah melihat kenyataan bahwa tidak hanya anak mereka 
saja yang mengalami hal serupa, bahkan masih banyak anak lain yang lebih parah lagi hambatannya. Sedangkan untuk subyek III, orang tua berhasil mengatasinya setelah mendapat nasehat dari anak yang lain.

Kecuali subyek III, ketiga subyek mengecek kebenaran akan klaim yang diberikan oleh guru subyek bahwa anak mereka tidak bisa untuk bersekolah di sekolah umum kepada psikolog. Di antara empat orang subyek, yang bersikap over protected terhadap anak adalah subyek II dan ke IV. Kasus pada subyek II dan IV sesuai dengan apa yang dikemukakan Jhonson (dalam Thompson \& Grabowsky, 1978) bahwa biasanya orangtua cenderung untuk bersikap over protected dan biasanya akan stres dan kaget ketika mengetahui kenyataan bahwa anak mereka tidak normal seperti yang lainnya.

\subsection{Bentuk Dukungan}

Pada umumnya, empat orang subyek memberikan dukungan dalam semua aspek sebagaimana yang diungkapkan oleh Sarafino (1998, dalam Aini 2001) yakni dukungan emosi, penghargaan, instrumental, informasi dan jaringan. Dukungan terbesar yang paling dibutuhkan dan diterima oleh 4 anak subyek ini adalah dukungan emosi dimana masing-masing subyek lebih memperhatikan dan mengistimewakan anak mereka sehubungan dengan ketunagrahitaan sang anak. Semua subyek memberikan pengertian penuh dan kesabaran dalam menghadapi anak sehingga anak sangat terbantu dengan dukungan tersebut.

Selain dukungan berupa kasih sayang dan perhatian, dukungan lain berupa pemberian informasi dan pengarahan dari subyek sangat membantu anak untuk bisa berperilaku secara adekuat. Pemberian informasi tersebut juga meliputi hal-hal seputar seksualitas anak. Dengan adanya informasi tersebut, anak lebih mampu untuk beradaptasi dengan perubahan yang terjadi pada dirinya baik dalam tataran pribadi maupun dalam tataran sosial.

Untuk subyek yang memiliki anak pria (I dan IV), dukungan yang masih perlu diberikan dalam aspek seksualitas tidak sebesar dukungan yang diperlukan oleh subyek yang memiliki anak wanita (II dan III). Dukungan yang paling dibutuhkan untuk aspek seksualitas lebih berupa pemberian informasi yang benar. Untuk anak dari subyek I dukungan yang dia butuhkan dari pihak lain terutama dari subyek lebih besar dibandingkan dengan anak dari subyek III baik itu dukungan untuk kebutuhan sehari-hari dan dukungan pada aspek seksualitas yang bersifat teknis. Hal ini disebabkan karena kecacatan anak.

Pada subyek II dan III, dukungan sangat diperlukan oleh anak pada saat anak mengalami menstruasi. Dukungan yang dibutuhkan meliputi pemberian informasi seputar masalah menstruasi termasuk dalam menjaga kebersihan dan pemberian bantuan secara teknis kepada anak. Dibandingkan dengan subyek III, anak dari subyek II membutuhkan dukungan yang lebih besar pada saat menstruasi. Hal ini kemungkinan besar disebabkan anak memiliki hendaya sekunder berupa cerebral palsy yang menyebabkan koordinasi motoriknya lemah. Selain itu, sikap subyek yang lebih ketat dalam menjaga anak juga turut memberikan 
sumbangan akan ketidakmandirian anak dalam hal menstruasi sampai saat ini. Sedangkan untuk subyek III, dukungan terbesar yang dibutuhkan anak berkaitan dengan menstruasi hanya diperlukan pada dua bulan pertama ketika anak mendapat menstruasi. Selanjutnya anak bisa melakukan semuanya sendiri meskipun kadang-kadang masih memerlukan bantuan dari orangtua atau dari subyek.

Diantara empat orang subyek yang diteliti, yang membutuhkan dukungan paling besar terutama dari pihak orangtua adalah anak dari subyek II. Hampir semua kebutuhan dari anak masih harus dibantu oleh subyek. Sedangkan subyek lain, hanya membutuhkan dukungan dalam aspek tertentu saja. Untuk anak dari subyek I, meskipun di rumah hampir semua kebutuhannya masih perlu mendapat dukungan, tapi hal itu lebih dikarenakan sifat manja dari anak dan juga karena anak memiliki cacat fisik di tangan.

\subsection{Pendidikan Seks}

Menurut Van Dyke et al (1995) isu mengenai seksualitas anak meliputi perkembangan dan perilaku seksual termasuk juga perubahan hormon dan fisik. Isu yang lain adalah mengenai pacaran dan pernikahan, reproduksi dan pengasuhan, hubungan seksual dan alat kontrasepsi, serta penyakit menular seksual.

Dalam aspek seksualitas, keempat individu penyandang tunagrahita bisa dikatakan normal. Organ-organ sekunder masing-masing individu berkembang selayaknya remaja normal. Hal ini sesuai dengan apa yang diungkapkan Schwab
(1992) bahwa anak penyandang tunagrahita memiliki rangkaian perubahan fisik dan hormon seperti anak normal lainnya. Untuk subyek yang memiliki anak pria (I dan IV), anak mengalami mimpi basah sedangkan untuk subyek yang memiliki anak wanita (II dan III) mengalami menstruasi. Hal ini menjadi indikasi bahwa dalam diri mereka telah terjadi rangkaian perubahan hormonal dan juga menunjukkan kalau mereka semua fertile/subur (Elkins et al, 1987 dalam Van Dyke et al, 1995).

Mengenai keinginan untuk berpacaran, ada anak yang sudah pernah berpacaran dengan sesama anak SLB. seperti pada anak dari subyek II dan IV. Sedangkan pada anak dari subyek lain sampai saat ini belum memiliki keinginan untuk berpacaran. Untuk anak dari subyek I, dia tidak menginginkan pasangan penyandang tunagrahita baik itu untuk dijadikan pacar maupun dijadikan istri. Dia lebih menginginkan hubungan dengan wanita yang normal. Sedangkan anak dari subyek III, sampai saat ini belum memiliki keinginan untuk pacaran atau menikah. Pada anak dari subyek II, dia sudah punya keinginan cukup besar untuk bisa mendapat pasangan seperti remaja yang normal. Hal ini terlihat dari upayanya mencari pasangan melalui majalah remaja. Anak juga sudah pernah mengungkapkan keinginannya untuk menikah tapi tidak mau menanggung salah satu konsekuensinya yakni terpisah dari orangtua. Sedangkan pada anak dari subyek IV, meskipun telah berpacaran sekali namun subyek belum memikirkan ke arah pernikahan. 
Dalam hal pemberian pemahaman seksualitas, keempat subyek telah memberikan informasi yang cukup jelas kepada anak mereka. Konsep tersebut meliputi norma dalam pacaran, pernikahan dan konsekuensinya, reproduksi dan pengasuhan. Kecuali subyek II, ketiga subyek juga sudah memberikan informasi mengenai pelecehan seksual dan cara untuk melindungi diri dari kemungkinan timbulnya hal tersebut. Subyek II tidak memberi informasi tersebut karena subyek menganggap bahwa pendampingan yang dia lakukan sudah cukup untuk melindungi anaknya dari kemungkinan timbulnya pelecehan seksual.

Mengenai konsep hubungan seks keempat subyek sudah memberikan informasi kepada anak secara cukup jelas. Namun untuk alat kontrasepsi, semua subyek belum memberikan penjelasan yang memadai kecuali untuk subyek IV pernah memberikan keterangan ringkas karena pada saat itu anak sempat bertanya pada subyek. Salah satu alasan yang timbul sesuai dengan apa yang diungkapkan dalam jurnal pediatrics Vol. 97 No.2 yang menyatakan bahwa orangtua enggan untuk membicarakan masalah seksualitas khususnya hubungan seks kepada anak karena ketakutan orangtua apabila pembicaraan mengenai seksualitas ini akan mendorong timbulnya perilaku seksual yang tidak diinginkan dan ketakutan akan kehamilan atau eksploitasi. Selain itu orangtua juga mengakui bahwa ada kesulitan dalam memutuskan tentang apa yang akan disampaikan dan bagaimana caranya. Alasan lain adalah adanya ketidakyakinan orangtua
Juni 2020 - November 2020 mengenai sejauh mana anak akan mengerti apa yang telah disampaikan. Tapi ada juga subyek seperti pada subyek I yang menganggap bahwa suatu hari subyek akan mengerti dengan sendirinya. Kecuali pada subyek II, rata-rata subyek sudah menjelaskan mengenai beberapa jenis penyakit menular seksual dan cara penularannya kepada anak.

Secara umum, subyek memahami pendidikan seks sebagai pelajaran mengenai hubungan seks antara pria dan wanita. Semua subyek merasa telah menerapkan pendidikan seks kepada subyek. Untuk subyek I, II, dan III, semuanya sepakat dengan pemberian pendidikan seks dalam rumah. Sedangkan pada subyek IV tidak terlalu setuju dengan pendidikan seks berdasarkan apa yang dia pahami yakni mengajarkan anak melakukan hubungan seks dengan menonton VCD porno. Dalam aspek seksualitas anak, peran subyek yang terbesar adalah berupa pemberian informasi dan pengarahan mengenai konsep-konsep yang berhubungan dengan aspek seksualitas anak. Untuk subyek I, II, dan IV, yang paling berperan dalam pendidikan seks dalam rumah adalah pihak ibu. Sedangkan untuk subyek III, peran pendidikan seks pada saat pihak ibu masih hidup tetap dipegang oleh sang ibu. Namun setelah ibu meninggal, maka peran tersebut sepenuhnya diambil alih oleh subyek.

Untuk subyek I, II, dan IV, aspek pendidikan seks yang paling ditekankan adalah mengenai aspek perawatan kebersihan tubuh. Berbeda dengan pihak lainnya, aspek pendidikan seks yang paling ditekankan oleh subyek III adalah 
pemahaman yang benar mengenai hubungan seks untuk mencegah terjadinya kehamilan yang tidak diinginkan di luar nikah. Mengenai harapan terhadap pemberian pendidikan seks, semua subyek hampir memiliki kesamaan yakni agar anak tidak mengalami masalah dalam aspek seksualitasnya yang akan berdampak negatif pada anak.

\section{Kesimpulan}

1. Semua orangtua dalam penelitian ini mempunyai reaksi yang serupa ketika mengetahui kenyataan bahwa anaknya mengalami ketunagrahitaan. Namun begitu, semuanya berhasil keluar dari kesedihan mereka dengan berbagai jalan seperti melalui pendekatan agama, melihat bahwa tidak hanya anak mereka saja yang tidak normal, atau dikarenakan dukungan dari anak-anak yang lain.

2. Secara umum, anak sudah bisa mandiri dalam beberapa aspek tertentu dan tidak membutuhkan dukungan yang terlalu besar. Hanya saja, mereka masih memerlukan kontrol yang cukup besar dari pihak orangtua terutama dalam aspek pelajaran. Hal ini dikarenakan hendaya dan kesulitan terbesar dari semua anak adalah dalam aspek pelajaran sekolah.

3. Dalam upaya pemberian pendidikan seks kepada anak tunagrahita mampu didik, orangtua memiliki peranan yang sangat besar. Bahkan bisa dikatakan bahwa anak mampu menyesuaikan diri dan berperilaku secara adekuat nyaris seratus persen atas peranan dari pihak orangtua. Dalam pemberian pendidikan seks ini,
Juni 2020 - November 2020 yang lebih berperan adalah pihak ibu.

4. Peran orangtua dalam pendidikan seks sebagian besar berbentuk informasi dan pengarahan mengenai konsep-konsep yang berhubungan dengan permasalahan seksualitas anak-anak. Cara penyampaian informasi tersebut yakni disesuaikan dengan kebutuhan dan konteks yang ada dan biasanya pada saat senggang. Penyampaiannya juga bersifat otodidak dan tidak sistematis. Rata-rata orangtua dalam penelitian ini memberitahukan kepada anaknya mengenai perubahan fisiologis yang terjadi dalam diri mereka setelah perubahan tersebut muncul atau hanya jika anak bertanya.

5. Dalam aspek seksualitas, dukungan yang paling dibutuhkan oleh anak adalah pemberian informasi yang benar sehubungan dengan aspek tersebut. Sumber informasi yang turut mendukung pemberian pemahaman mengenai aspek seksualitas adalah dari TV dan majalah. Khusus untuk wanita, mereka juga membutuhkan dukungan secara teknis dan tidak hanya informasi dalam hal menstruasi. Informasi yang telah diberikan orangtua kepada anak sehubungan dengan masalah seksualitas adalah norma-norma dalam pacaran, pernikahan dan konsekuensinya, reproduksi dan pengasuhan, pelecehan seksual dan bagaimana cara melindungi diri, penyakit menular seksual, dan dampak negatif jika terlalu sering melakukan onani dan masturbasi.

6. Orangtua yang memiliki anak tunagrahita yang berjenis kelamin pria memiliki peranan yang berbeda dengan orangtua 
yang memiliki anak tunagrahita yang berjenis kelamin wanita. Perbedaan yang dimaksud adalah perbedaan dalam pemberian dukungan kepada anak dalam aspek seksualitas anak. Orangtua yang memiliki anak tunagrahita wanita menjalankan peran yang lebih besar dibandingkan dengan orangtua dengan anak tunagrahita pria. Peran tersebut berkaitan dengan menstruasi yang dialami oleh anak tunagrahita wanita dimana orangtua tidak hanya memberikan informasi tapi juga turut terlibat dalam membantu anak secara teknis.

7. Untuk informasi mengenai hubungan seks dan alat kontrasepsi, orangtua dari semua anak belum memberikan informasi yang berkaitan dengan permasalahan tersebut secara terarah dan intens seperti halnya pada aspek lain. Namun mereka tetap punya rencana untuk menyampaikan hal itu kepada anak. Hanya saja kendala yang dihadapi dalam penyampaian hubungan seks dan alat kontrasepsi, subyek belum tahu bagaimana cara penyampaiannya dan kapan waktu yang tepat untuk menyampaikan hal tersebut. Selain itu, subyek juga menganggap bahwa anak tidak akan mengerti mengenai informasi seks yang akan disampaikan karena gangguan dalam fungsi intelektualitas yang dialami anak.

8. Secara umum, orangtua dalam penelitian ini telah menerapkan pendidikan seks kepada anak meskipun bisa dikatakan terlambat mengingat rata-rata orangtua atau significant others menyatakan bahwa mereka akan mulai memberikan
Juni 2020 - November 2020 pemahaman secara utuh pada saat anak akan menikah. Rata-rata orangtua menekankan pada pemberian informasi mengenai perawatan kebersihan tubuh. Faktor utama yang membuat orangtua menerapkan pendidikan seks agar anak bisa terhindar dari hal-hal yang merugikan sehubungan dengan aspek seksualitas. Faktor ini juga yang menjadi harapan orangtua agar bisa dicapai melalui pemberian pendidikan seks.

\section{Kepustakaan}

Abdul, R., Khan, G., Khan, F. A., \& Khan, M. A. (2011). Impact of Training and Development on Organizational Performance, 11(7).

Amstrong, M. (2000). "Understanding Training". Human Resource Management Practice (8th Edition). London: Kogan page limited.

Bramley, P. (2019). Evaluating Training (2nd ed.). UK: CIPD UK.

Bullock. (2012). Professional Development For Your Employees. Retrieved from http://www.scontrinopowell.com/2012/professionaldevelopment-for-your-employees---asound-investment/

Ginsberg, L. (1997). Training for the Long Haul. Computer Shopper, Vol. 17, 4.

Iftikhar, A., \& Din, G. S. ud. (2009). EVALUATING TRAINING AND DEVELOPMENT. Pakistan: Gomal Medical College and Gomal University, D.I.Khan.

Karim, M. R., Huda, K. N., \& Khan, R. S. (2012). Significance of Training and Post Training Evaluation for Employee Effectiveness: An Empirical Study on Sainsbury' s Supermarket Ltd , 7(18), 
141-148.

https://doi.org/10.5539/ijbm.v7n18p14

1

Kirkpatrick Level 3 Survey Questions. (n.d.), 3.

Lee, C., Esen, E., \& DiNicola, S. (2017).

Employee Job Satisfaction and Engagement: The Doors of Opportunity Are Open, 1-12.

Partlow, C. G. (1996). Human-Sesources Practices of TQM Hotels. Cornell Hotel \& Restaurant Administration Quarterly, Vol. 37 No, 67-77.

Pilbeam, S., \& Corbridge, M. (2002). People Resourcing: HRM in practice (2nd ed.). UK: Financial times prentice hall.

Tsaur, S. H., \& Lin, Y. C. (2004). Promoting Service Quality in Tourist Hotels: The Role of HRM Practices and Service Behavior. Tourism Management, 25, 471. 